\title{
Evaluation of Retailers' vs Customers' Views on the Usage of Advertising as Communication Tool
}

\author{
Hemant J. Katole ${ }^{1}$ \\ ${ }^{1}$ Department of Management Sciences (PUMBA), University of Pune, Pune, India \\ Correspondence: Hemant J. Katole, Department of Management Sciences (PUMBA), University of Pune, Pune \\ 411007, India. E-mail: hjkatole@gmail.com
}

\author{
Received: September 1, 2012 Accepted: October 23, 2012 Online Published: November 14, 2012 \\ doi:10.5539/ijms.v4n6p174 URL: http://dx.doi.org/10.5539/ijms.v4n6p174
}

\begin{abstract}
The basic objective of research paper is to understand the Communication mix strategies adopted by organized retail sector specially related with advertising as a communication tool, and to identify and analyze communication gap between the views of retailer and customer regarding the usage of advertising media as communication tool. Retail advertising is advertising given by the retailers unswervingly to the consumers. Researcher conduct the study of advertising media which includes Cable Television, Newspaper, radio, Hoardings/Billboards, Leaflets/flyers, Magazine, Website / Internet, E-mail. While deciding the sample size of retailers, researcher used disproportionate stratified sampling techniques. The actual survey was conducted amongst store managers of supermarkets, department stores and hypermarket in Pune and PCMC area. Along-with, the primary data was collected amongst customers also. Total 63 store managers and 200 customers were covered for this study. Researcher found out that organized retailers commonly used newspaper, hoardings, leaflets, internet and e-mail to communicate with the customers. In this study, researcher also found out positive \& negative communication gap between the views of retailer and customer.
\end{abstract}

Keywords: retail advertising, retail communication mix, retail communication gap

\section{Introduction}

Retailing is resulting from the French word "retaillier" and the meaning is breaking the bulk into pieces. Retailing includes a direct interaction with the customer and the harmonization of business activities from end to end, right from the idea generation stage of a product, to its delivery and post delivery service to the customer. Retailers are using sophisticated communication and information systems to manage their businesses. The most important tool for communicating with the customer is advertising that is retail advertising. An approach to paying for retail advertising whereby the advertising space or time is placed by a local retail store but is partly or fully paid for by a national manufacturer whose product is featured in the advertising. Generally, advertising is done by the manufacturer of the product. Quite often, the retailer carries out some of this advertising. Such advertising focuses almost exclusively on the single attributed product. Those retailers who desire to begin a large scale campaign may, of course, resort to advertising via Cable Television, Newspaper, radio, Hoardings/Billboards, Leaflets/flyers, Magazine, Website / Internet, E-mail. The advertising campaign will be successful if the advertising frequency increase up to five to six times during one or two week so that the customer would aware with the service or product and most important with the store.

\section{Review of Literature}

In strategic retail literature, retail advertising is described by very similar typologies, that distinguishes between short term (promotional advertising) - and long term (corporate advertising) (Cox \& Brittain, 1993), or promotional and institutional advertising (Hathcote, 1995).

Rossiter \& Percy (1997) focuses on the two brands a retailer has to advertise: the products sold and the store brand. Fulop (1988) points out how the retailer mix is composed from a differentiation strategy to promote the store through the retailer name.

All the sources emphasise the main goals/objectives as increasing store traffic, creating store loyalty, stabilise volume and placing the store in the consumers' mind (Hathcote, 1995). These distinctions are based on 
short/long term objectives, Circulars are mentioned by very few words, and a clear definition does not exist, but they are viewed as short term/promotional advertising activities (Cox \& Brittain, 1993).

Wells, Moriarity, and Burnett (2006) observe that retail advertising focuses on influencing where customers purchase rather than simply what they purchase. Retail advertising basically contain the information about variety of products and also includes the specific offers provided by retailers and detail purchase method about the store which include the information about shopping hours, ordering options together with directions to the retailer's Internet or physical stores, acceptable payment methods. On the other hand, manufacturer advertising rarely contains information about multiple products or details about shopping hours or payment methods (though it is not unusual to identify alternative retailers).

Hypothetical advertising has focused on advertising a persuasive or informative role. In persuasive view, advertising go through customers' usefulness for diverse products (Becker and Murphy 1993; Comanor and Wilson 1967, 1974; Kaldor 1950). This guide to an outward shift in the demand function, which has led to declare that advertising might serve an significant anticompetitive role. In informative view, advertising boost the information that customers have about the existing choices (Kihlstrom and Riordan 1984; Milgrom and Roberts 1986; Stigler 1961).

Borden (1942) compares primary and selective effects of advertising: the primary effect explains category-level demand expansion, while the selective effect explains replacement between competing brands. Recently, the difference between advertising's primary and selective effects has served as a central focus of discussion in the tobacco industry (Roberts and Samuelson 1988; Seldon and Doroodian 1989). The industry has required to ward off projected instruction limiting tobacco advertising by arguing that advertising provides primarily a selective role, allowing companies to attract share from their competitors without increasing total industry demand.

Research paper on how advertising influences prices and price elasticities written by Krishnamurthi and Raj (1985) report the findings from a split-sample cable television research and conclude that advertising is able of dropping consumer price elasticities. Milyo and Waldfogel (1999) use a natural experiment to study the effect of retail advertising on prices. They find that advertising does likely to lower the retail prices of advertised products but has slight effect on the prices of unadvertised products. Other research also includes advertisement message and the influence of response rate. Bertrand et al. (2006) use a randomized directmail experiment to measure how changing features of an advertisement for consumer credit affected the response rate.

\section{Research Objectives}

1) To understand the Communication mix strategies adopted by organized retail sector specially related with advertising as a communication tool.

2) To identify and analyze communication gap between the views of retailer and customer regarding the usage of advertising as communication tool.

\section{Research Hypothesis}

There is a gap between the views of retailer and customer regarding the usage of advertising as communication tools.

\section{Research Methodology}

The secondary data was compiled through various magazines and journals like journal of retailing, retailers and others. Various websites were also referred. Structured questionnaires were developed and pilot survey was carried out. The questionnaires were then suitably modified and the primary data on various aspects of publicity was collected. The actual survey was conducted amongst store managers of supermarkets, department stores and hypermarket in Pune and PCMC area. Along-with, the primary data was collected amongst customers. Total 63 store managers and 200 customers were covered for this study.

While deciding the sample size of retailers, researcher used disproportionate stratified sampling techniques. The retailers' questionnaire was mainly focused on types of retailer (Supermarket, Department store \& Hypermarket), objective of retail firm, usage of tools of communication, medias used for placing the various publicity tools. Collection of primary data by interviewing with retailers which includes,

Supermarket: Reliance Fresh, More, Spencer's.

Hypermarket: Big Bazaar, Pune Central

Department Store: Reliance Mart, Shoppers’ Stop, Westside, K.K. Bazaar, Vishal Mega Mart, Fabindia. 


\section{Data Analysis}

Researcher has mainly found out the retailers' usage of advertising media. The following table highlights on the utilization of these media. The basic Advertisement media used by the retailers are Cable Television, Newspaper, Radio, Hoarding, Leaflets, Magazine, Internet, and E-mail. Table no 1 \& Graph no. 1.

Table 1. Usage of advertising media by retailer

\begin{tabular}{llll}
\hline & $\mathbf{4}$ & $\mathbf{5}$ & Total \\
\hline $\begin{array}{lll}\text { Advertising } \\
\text { Media }\end{array}$ & $(\%)$ & $(\%)$ & \\
Cable Television & 14 & 10 & $\mathbf{2 4}$ \\
Newspaper & 37 & 51 & $\mathbf{8 8}$ \\
Radio & 18 & 19 & $\mathbf{3 7}$ \\
Hoarding & & & \\
/Billboards & 47 & 33 & $\mathbf{8 0}$ \\
Leaflets & 32 & 37 & $\mathbf{6 9}$ \\
Magazine & 18 & 2 & $\mathbf{2 0}$ \\
Internet & 45 & 14 & $\mathbf{5 9}$ \\
Email & 37 & 18 & $\mathbf{5 5}$ \\
\hline
\end{tabular}

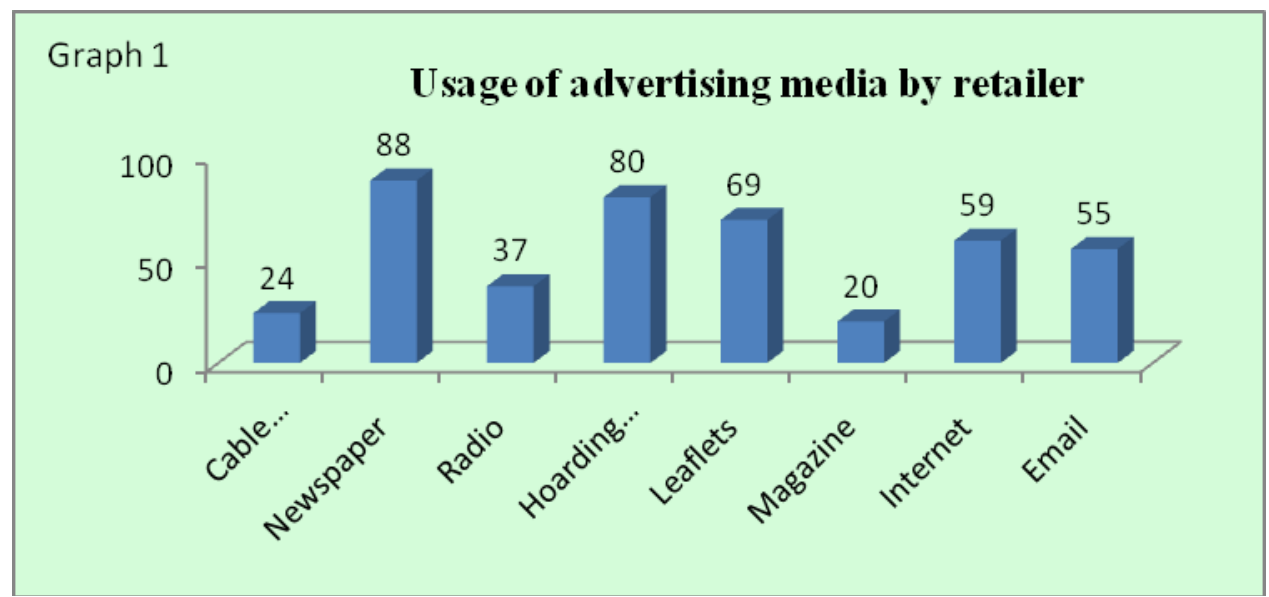

Graph 1. Usage of advertising media by retailer

The table shows that organized retailers commonly used Newspaper (88\%), Hoardings (80\%), Leaflets $(69 \%)$, Internet (59\%) and E-mail (55\%) to communicate with the customers.

Researcher conducted the survey of three types of retailers which include Supermarkets, Departmental Stores and Hypermarkets. The priority wise utilization of advertising media by these types of retailers is as follows, Table no 2 \& graph no 2,3 and 4.

Table 2. Priority wise usage of advertising media by retailers

\begin{tabular}{lllllll}
\hline Priority & Supermarket & $\begin{array}{l}\text { \% usage of } \\
\text { retailer }\end{array}$ & Departmental Store & $\begin{array}{l}\text { \% usage of } \\
\text { retailer }\end{array}$ & Hypermarket & $\begin{array}{l}\text { \% usage of } \\
\text { retailer }\end{array}$ \\
\hline 1 & Leaflets & 83 & $\begin{array}{l}\text { Newspaper } \\
\text { Hoardings/ }\end{array}$ & 92 & $\begin{array}{l}\text { Internet } \\
\text { Newspaper \& }\end{array}$ & $\begin{array}{l}100 \\
\text { Hoardings /Billboards }\end{array}$ \\
2 & Newspaper & 80 & $\begin{array}{l}\text { Billboards } \\
\text { Internet }\end{array}$ & 80 & E-mail & 90 \\
3 & Hoardings/ & 67 & & & \\
4 & Billboards & & E-mail & 75 & Radio & 89 \\
5 & Internet & 30 & Radio \& Leaflets & 50 & Cable TV \& Leaflets & 67 \\
\hline
\end{tabular}



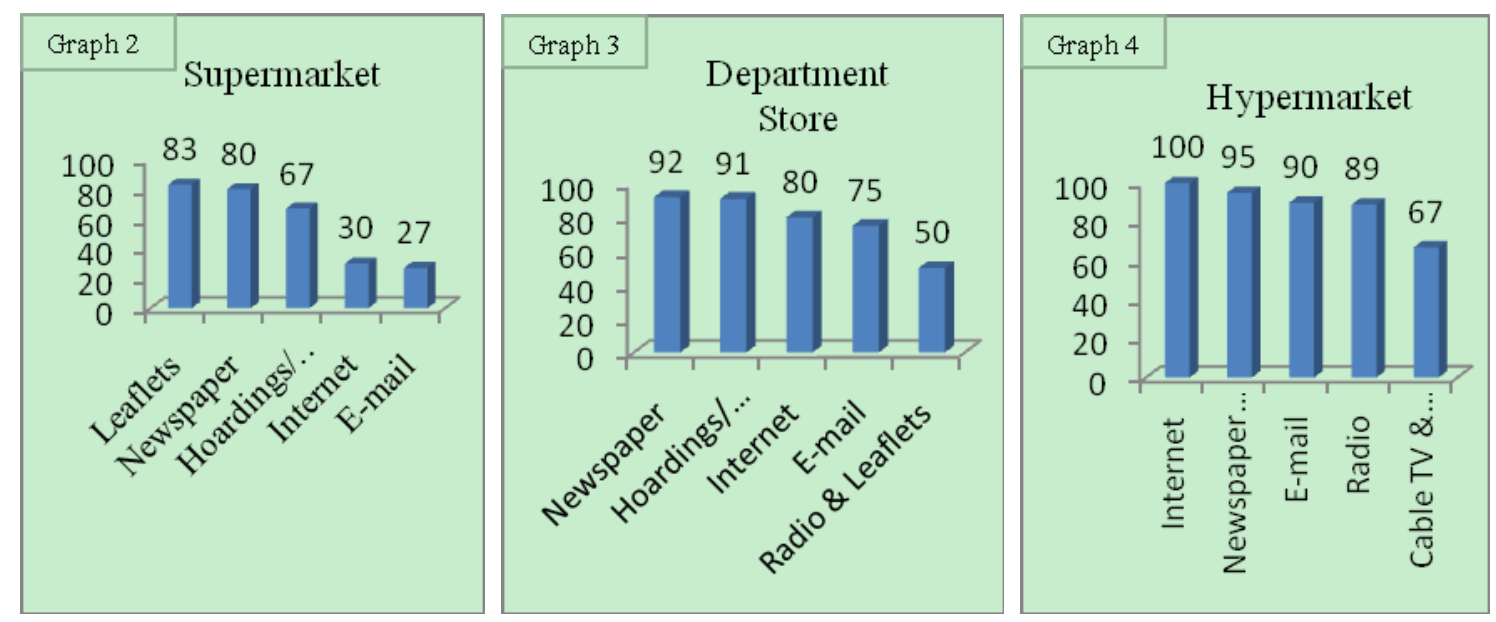

Graph 2, 3 \& 4. Priority wise usage of advertising media by supermarket, department store, hypermarket

From the above analysis, researcher found that the priority wise usage of advertising media by supermarkets, departmental stores and hypermarkets is as follows,

Supermarkets give priority to leaflets (83\%), newspaper (80\%) and hoardings (67\%); while departmental stores give priority to newspaper (92\%), hoardings (91\%) and Internet (80\%); and hypermarkets give priority to Internet (100), newspaper \& hoardings (95\%) and E-mail (90\%).

Hence, researcher concludes that the preferred advertising media used by organized retailers are newspaper, hoardings, leaflets, internet, e-mail, magazine, radio and cable television.

Hypothesis: There is a gap between the views of retailer and customer regarding the usage of advertising as communication tools.

H0: There is a no gap between the views of retailer and customer regarding the usage of advertising as communication tools.

H1: There is gap between the views of retailer and customer regarding the usage of advertising as communication tools.

From this hypothesis; the researcher wants to find out the GAP between communication tools used by the retailer for communicating with the customer and the tools used by the customer for collecting the information about the retailer/ store. In this study researcher consider advertising as communication tool. Researcher has used percentage method, ranking by calculating variance method to test this hypothesis. And by using Z-test, researcher found out the communication gap for the population. The detail explanation about the gap between the usage of communication tools by retailer and customers is as follows.

6.1 The Views of Retailers and Customers about the Relationship between Usage of Advertising and Different Media Used for Placing Advertisements

Table 3. Relationship between usage of advertising \& their media

\begin{tabular}{|c|c|c|c|c|c|c|c|c|}
\hline \multirow[b]{2}{*}{$\begin{array}{l}\text { Advertising } \\
\text { Media }\end{array}$} & \multicolumn{4}{|c|}{ Retailer's View } & \multicolumn{4}{|c|}{ Customer's View } \\
\hline & Mean & $\begin{array}{l}\text { Std. } \\
\text { Deviation }\end{array}$ & $\begin{array}{l}\text { Std.Deviatio } \\
\text { n/Mean }\end{array}$ & Rank & Mean & $\begin{array}{l}\text { Std. } \\
\text { Devia } \\
\text { tion }\end{array}$ & $\begin{array}{l}\text { Std.Deviation/ } \\
\text { Mean }\end{array}$ & Rank \\
\hline Cable Television & 2.28 & 1.39618 & 0.61083256 & 8 & 3.2 & 1.417 & 0.4428125 & 7 \\
\hline Newspaper & 4.30 & 0.90936 & 0.21140040 & 1 & 4.06 & 1.013 & 0.249507389 & 1 \\
\hline Radio & 2.98 & 1.38532 & 0.46423377 & 7 & 3.52 & 1.207 & 0.342897727 & 2 \\
\hline Hoardings & 4.03 & 0.94984 & 0.23559292 & 2 & 3.4 & 1.203 & 0.353823529 & 3 \\
\hline Leaflets & 3.90 & 1.08827 & 0.27870057 & 3 & 2.99 & 1.288 & 0.430769231 & 6 \\
\hline Magazine & 2.44 & 1.10392 & 0.45161184 & 6 & 3.29 & 1.274 & 0.387234043 & 4 \\
\hline Internet & 3.53 & 1.02902 & 0.29070825 & 4 & 3.33 & 1.292 & 0.387987988 & 5 \\
\hline \multirow[t]{2}{*}{ Email } & 3.52 & 1.04507 & 0.29657472 & 5 & 2.93 & 1.414 & 0.482593857 & 8 \\
\hline & \multicolumn{4}{|c|}{$\begin{array}{l}\text { 1. Newspaper, } 2 \text {. Hoarding, } 3 \text {. Leaflets \& } 4 . \\
\text { Internet }\end{array}$} & \multicolumn{4}{|c|}{$\begin{array}{l}\text { 1. Newspaper, 2. Radio. 3. Hoarding \& } 4 \\
\text { Magazine }\end{array}$} \\
\hline
\end{tabular}


RETAILERS' VIEWS: From the above analysis; it is observed that the media preferred by the retailers for placing their advertisements are Newspapers, Hoardings, Leaflets, Internet, E-mail, Magazines, and Radio.

CUSTOMERS' VIEWS: From the above analysis; it is observed that the media preferred by customers for collecting information about the store are Newspapers, Radio, Hoardings, Magazines, Internet, Leaflets, Cable Television, and E-mail.

From the above analysis, it is clear that both the retailers and customers have ranked Newspapers as the most preferred medium for placing their advertisements. The other advertisement media used by the customers for collecting the information about the store are radio, hoardings, magazines, and internet. Hence, alongwith newspapers, the retailers should also use radio, hoardings, magazines and internet as advertisement media for placing their advertisements.

\subsection{Communication Gap Analysis by Comparison of Retailers' vs Customers' Views on the Usage of Advertisement Media}

There is communication gap between Retailers' and Customers' views on Advertisement as communication tool and the media used for placing the advertisements.

The researcher found out the GAP between advertisement media used by the retailers and the advertisement media used by the customers for collecting the information about the retailer.

Table 4. Comparison of retailer \& customer about the usage of advertisement media

\begin{tabular}{llllllll}
\hline & \multicolumn{2}{l}{\begin{tabular}{l} 
Usage $\begin{array}{l}\text { of Retailer's } \\
\text { Communication }\end{array}$ \\
\cline { 2 - 6 } Tools
\end{tabular}} & $\begin{array}{l}\text { Customer's } \\
\text { information collection } \\
\text { tools }\end{array}$ & \\
\cline { 2 - 6 } Advertising Media & $\begin{array}{l}4 \\
(\%)\end{array}$ & $\begin{array}{l}\text { Total } \\
(\mathrm{A})\end{array}$ & $\begin{array}{l}4 \\
(\%)\end{array}$ & $\begin{array}{l}5 \\
(\%)\end{array}$ & $\begin{array}{l}\text { Total } \\
(\mathrm{B})\end{array}$ & Communication GAP \\
\hline Cable Television & 14 & 10 & 24 & 16 & 27 & 43 & Positive communication gap \\
Newspaper & 37 & 51 & 88 & 31 & 43 & 74 & Negative communication gap \\
Radio & 18 & 19 & 37 & 30 & 26 & 56 & Positive communication gap \\
Hoarding & 47 & 33 & 80 & 34 & 19 & 53 & Negative communication gap \\
Leaflets & 32 & 37 & 69 & 24 & 15 & 39 & Negative communication gap \\
Magazine & 18 & 2 & 20 & 26 & 21 & 47 & Positive communication gap \\
Internet & 45 & 14 & 59 & 28 & 22 & 50 & No communication gap \\
Email & 37 & 18 & 55 & 19 & 19 & 38 & Negative communication gap \\
\hline
\end{tabular}

The researcher also found out whether there is a gap between the views of retailers and customers based on advertisement media. For this, researcher tested whether there are differences between two population proportions.

Table 5. Z-test analysis regarding the usage of advertisement media

\begin{tabular}{|c|c|c|c|}
\hline Sr. no. & Advertisement Media & $\begin{array}{l}\text { Z-test } \\
-1.96<(\text { z-value })<+1.96\end{array}$ & Communication GAP \\
\hline 1 & $\begin{array}{l}\text { Cable television as Advertisement media: } \\
\text { Retailer: } 24 \% \text {, Customer : } 43 \%\end{array}$ & -2.959 & Positive communication gap \\
\hline 2 & $\begin{array}{l}\text { Newspaper as Advertisement media : } \\
\text { Retailer: } 88 \% \text {, Customer : } 74 \%\end{array}$ & 2.72 & Negative communication gap \\
\hline 3 & $\begin{array}{l}\text { Radio as Advertisement media : Retailer: } \\
88 \% \text {, Customer : } 74 \%\end{array}$ & -3.699 & Positive communication gap \\
\hline 4 & $\begin{array}{l}\text { Hoarding/billboard as Advertisement } \\
\text { media : } \\
\text { Retailer: } 88 \% \text {, Customer : } 74 \%\end{array}$ & 4.39 & Negative communication gap \\
\hline 5 & $\begin{array}{l}\text { Leaflets as Advertisement media : } \\
\text { Retailer: } 69 \% \text {, Customer : } 39 \%\end{array}$ & 4.63 & Negative communication gap \\
\hline 6 & $\begin{array}{l}\text { Magazine as Advertisement media } \\
\text { Retailer: } 20 \% \text {, Customer : } 47 \%\end{array}$ & -4.38 & Positive communication gap \\
\hline 7 & $\begin{array}{l}\text { Internet as Advertisement media } \\
\text { Retailer: } 59 \% \text {, Customer : } 50 \%\end{array}$ & 1.26 & No communication gap \\
\hline 8 & $\begin{array}{l}\text { E-mail as Advertisement media : Retailer: } \\
55 \% \text {, Customer : } 38 \%\end{array}$ & 2.37 & Negative communication gap \\
\hline
\end{tabular}


There are two types of communication gaps;

1) Positive communication gap: Usage of Communication tools by the retailers for communicating with the customers is LESS than the usage of Communication tools by the customers for collecting the information about the retailers.

2) Negative communication gap: Usage of Communication tools by the Retailers for communication with the customers is MORE than the usage of Communication tools by the customers for collecting the information about the retailers.

From the above analysis using $\mathrm{Z}$ test researcher concludes that there is communication gap between the views of retailers \& customers in terms of usage of advertisement media.

1) There is positive communication gap between retailers and customers for usage of cable television, radio, and magazines as advertisement media.

2) There is negative communication gap between retailers and customers for usage of hoardings, newspaper, E-mail and leaflets as advertisement media.

3) There is no communication gap between retailers and customers for usage of Internet as advertisement media.

\section{Findings of Research}

4) From the above analysis, it is clear that both the retailers and customers have ranked Newspapers as the most preferred medium for placing their advertisements. The other advertisement media used by the customers for collecting the information about the store are radio, hoardings, magazines, and internet. Hence, along with newspapers, the retailers should also use radio, hoardings, and magazines \& internet as advertisement media for placing their advertisements.

5) The basic advertisement media used by the retailers and customers are cable television, newspapers, radio, hoardings, leaflets, magazines, Internet, and E-mail. As can be seen from the table; the retailers commonly use Newspapers (88\%), Hoardings (80\%), Leaflets (69\%), Internet (59\%) and E-mail (55\%) to communicate with the customers. While Customers mostly collect information through Newspapers (74\%), Radio (56\%), Hoardings (53\%) and Internet (50\%).

6) Advertisement media, there is positive communication gap between retailers and customers for usage of cable television, radio, and magazines as advertisement media. There is negative communication gap between retailers and customers for usage of hoardings, newspaper, E-mail and leaflets as advertisement media. There is no communication gap between retailers and customers for usage of Internet as advertisement media.

7) For Supermarkets, there is positive communication gap between Retailers and Customers for usage of cable television, radio, Internet, and magazines as advertisement media. There is negative communication gap between Retailers and Customers for usage of hoardings, and leaflets as advertisement media. There is no communication gap between Retailers and Customers for usage of newspapers and E-mail as advertisement media.

8) For department stores, there is positive communication gap between Retailers and Customers for usage of cable television and magazines as advertisement media. There is negative communication gap between Retailers and Customers for usage of newspapers, hoardings, Internet and E-mail as advertisement media. There is no communication gap between Retailers and Customers for usage of radio, and leaflets as advertisement media.

9) For hypermarkets, there is positive communication gap between Retailers and Customers for usage of Magazine as advertisement media. There is negative communication gap between Retailers and Customers for usage of cable television, newspapers, radio, hoardings, leaflets, Internet and E-mail as advertisement media.

\section{Suggestions of Research}

1) Researcher found out the communication gap between retailer and customer views on the usage of advertisement media, which includes positive \& negative communication gap. Because of the negative communication gap between retailers and customers, researcher suggests that the retailer's, usage of leaflets as an advertisement media should be reduced upto $30 \%$, usage of hoardings as an advertisement media should be reduced upto $27 \%$, usage of e-mail as an advertisement media should be reduced upto $17 \%$, usage of 
newspaper as an advertisement media should be reduced upto $14 \%$, usage of internet as an advertisement media should be reduced upto $9 \%$.

2) Also from the study it was observed that the positive gap exist in the usage of cable television, radio and magazine which exceeds utilization of advertisement budget. Hence researcher also suggests that the retailers' usage of magazine as an advertisement media should even reduce upto $27 \%$, usage of cable television as an advertisement media should even reduce upto $19 \%$, and usage of radio as an advertisement media should even reduce upto $19 \%$.

\section{Limitations of Research}

The study was limited to three types of retail formats (supermarket. department store, hypermarket); thus, generalization of the research results is somewhat limited. Secondly, the study was confined to Pune city only while other urban, rural, and semi urban area was not covered. Third, during the pilot study, researcher found that the marketing managers are very busy and are not available; hence researcher developed a questionnaire which can be effortlessly filled by the store managers who are easily available. Fourth, despite best efforts, researcher could not get all the information due to lack of respondents' interest.

\section{Scope for Future Research}

1) To conduct this study on other types of retail formats other than supermarkets, department stores and hypermarkets.

2) To conduct this study in unorganized retail sector.

3) To conduct this study on all India basis including urban, rural \& semi-urban markets.

4) To test the framework on a wider scale before implementation.

5) To repeat this study periodically to measure the impact of retail communication elements.

\section{Conclusions}

Retail advertising and promotion search how today's retailers can successfully reach their existing consumer base, attract new shoppers to their companies, and turn those shoppers into customers. Retail media guide have become established as gradually more important for promoting goods and services at or near or even further beyond the points of purchase and consumption. Retail Media created as media available within the retail environment. In this study firstly researcher focuses on the relationship between advertising and different media used for placing advertisements. From the analysis, it is clear that both the retailers and customers have ranked newspapers as the most preferred medium for placing their advertisements. The other advertisement media used by the customers for collecting the information about the store are radio, hoardings, magazines, and internet. Hence, along with newspapers, the retailers should also use radio, hoardings, and magazines $\&$ internet as advertisement media for placing their advertisements. Secondly the researcher focuses on the communication gaps between Retailers and Customers in terms of usage of advertisement media, It is found out that the positive gap exists in the media includes cable television, radio, magazine while the negative gap exists in the media includes newspaper, hoardings, leaflets and e-mail.

\section{References}

Aaker, D. A., \& Carman, J. M. (1982). Are you over advertising? Journal of Advertising Research, 22(4), 57-70.

Abernethy, A. M., \& Franke, G. R. (1996). The information content of advertising: a meta-analysis. Journal of Advertising, 25(2), 1-17.

Armstrong \& Mark. (2006). Competition in Two-Sided Markets. RAND Journal of Economics, 37(September), 668-91.

Assmus, G., Farley, J., \& Lehmann, D. (1984). How advertising affects sales: meta-analysis of econometric results. Journal of Marketing Research, 21(1), 65-74.

Bergemann, D., \& Alessandro, B. (2010). Targeting in Advertising Markets: Implications for Offline vs. Online Media. Cowles Foundation Discussion Paper 1758, Yale University.

Bruner, G. C. II, \& Kumar, A. (2000). Web commercials and advertising hierarchy-of-effects. Journal of Advertising Research, 40(1/2), 35-42.

Bush, A. J., Bush, V., \& Harris, S. (1998). Advertiser perceptions of the internet as a marketing communications tool. Journal of Advertising Research, 38(2), 7-27.

Carter, C., \& Steiner, L. (2004). Critical Readings: Media and Gender. Open University Press, Milton Keynes. 
Chan, K. K. W. (1995). Information content of television advertising in China. International Journal of Advertising, 14, 365-73.

Cho, C. L. J., \& Tharp, M. (2001). Different forced exposure levels to banner advertisements. Journal of Advertising Research, 41(4), 45-56.

Colley, R. H. (1961). Defining Advertising Goals for Measured Advertising Results. Association of National Advertisers, Inc., New York, NY.

Ducoffe, R. H. (1996). Advertising value and advertising on the web. Journal of Advertising Research, 36(5), 21-35.

Ellman, M., \& Fabrizio, G. (2009). What Do the Papers Sell? A Model of Advertising and Media Bias. Economic Journal, 119(April), 680-704.

Faigin, T. L. (1997). Using the web as a marketing tool: introducing a new medium into the media mix. IMC Research Journal, 3(1), 40-53.

Gabszewicz, J. J., Didier L., \& Nathalie S. (2002). Press Advertising and the Political Differentiation of Newspapers. Journal of Public Economic Theory, 4(July), 317-34.

Gentzkow, M., \& Jesse, M. S. (2006). Media Bias and Reputation. Journal of Political Economy, 114(April), 280-316.

Groseclose, T., \& Jeffrey, M. (2005). A Measure of Media Bias. Quarterly Journal of Economics, 120 (November), 1191-1237.

Guo, L. (2006). Consumption Flexibility, Product Configuration, and Market Competition. Marketing Science, 25(March/ April), 116-30.

Henry, C., Raymond, L., Tharam, D., \& Elizabeth, C. (392). E-Commerce Fundamentals \& Applications. Jonhs Willy \& Sons Inc. UK.

Hirschman, E. A., \& Thompson, C. J. (1997). Why media matter: toward a richer understanding of consumers' relationships with advertising and mass media. Journal of Advertising, 26(1), 43-60.

http://en.mimi.hu/marketingweb/retail_advertising.html

http://en.wikipedia.org/wiki/Retailing_in_India

http://hubpages.com/hub/Advatages-of-Internet-Advertising

http://marketingpedia.com/

http://www.sideroad.com/Business_Communication/advantage-of-radio- advertising.html

http://www.websitemarketingplan.com/small_business/magazine.htm

http://www.websitemarketingplan.com/small_business/newspaper.htm

Iyer, G., David S., \& Villas-Boas, J. M. (2005). The Targeting of Advertising. Marketing Science, 24(Summer), 461-76.

James \& Hamilton. (2004). All the News That's Fit to Sell: How the Market Transforms Information into News. Princeton, NJ: Princeton University Press.

Moorman, M., Neijens, P. C., \& Smit, E. G. (2002). The effects of magazine-induced psychological responses and thematic congruence on memory and attitude toward the ad in a real-life setting. Journal of Advertising, 31(4), 27-40.

Mullainathan, S., \& Andrei, S. (2005). The Market for News. American Economic Review, 95(September), 1031-53.

Naccarato, J. L., \& Neuendorf, K. A. (1998). Content analysis as a predictive methodology: recall, readership, and evaluations of business-to-business print advertising. Journal of Advertising Research, 38(3), 19-33.

Russell \& Belk. (1988). Possessions and the Extended Self. Journal of Consumer Research, September, 139-68.

Sarvary, M., \& Philip, P. (1997). Marketing Information: A Competitive Analysis. Marketing Science, 16(Winter), 24-38.

Strömberg, D. (2004). Mass Media Competition, Political Competition, and Public Policy. Review of Economic Studies, 71(January), 265-84. 
Xiang, Y., \& Miklos, S. (2007). News Consumption and Media Bias. Marketing Science, 26(September/October), 611-28. 